\title{
Bicameralism: European Tendencies and Perspectives for Ukraine
}

\author{
Vasyl Tatsiy \\ Yaroslav Mudryi National Law University \\ Pushkinska 77, \\ Kharkiv 61024, Ukraine \\ E-mail: kancel@nulau.edu.ua
}

Svitlana Serohina

Scientific Research Institute of

State Building and Local Government of National Academy of Law Sciences of Ukraine

Chernyshevska 80,

Kharkiv 61002, Ukraine

E-mail: ndi_db_ms@ukr.net

Abstract: The authors of the article continue the scientific discourse on the role and significance of bicameralism for building a modern democratic legal state. The main arguments of supporters and opponents of bicameralism have been analysed, given the complicated development of Ukrainian institutional framework and discussions over the European Committee of Regions evolution. The authors of the article attempt to supplement the list of arguments that exist in modern legal literature in favor of Ukraine's transition to bicameralism. The challenges of European integration for Ukrainian parliament as a unitary actor have been highlighted. The authors substantiate the thesis that the formation of the second (upper) chamber does not threaten the Ukrainian unitarianism, but will contribute to further diversification of state power and at the same time increase the stability of the government in terms of a consensual, pluralistic democracy and semi-presidential government.

Keywords: bicameralism, constitutional reform, diversification of power, parliament, upper chamber 


\section{Introduction}

The problem of choosing the optimal structure of the parliament, in particular the resolution of the issue of the number of its chambers, the procedure of their formation and competence, belongs to the category of those that accompany the theory and practice of state building since the emergence of the first parliamentary institutions and the concept on the representative government. It has not lost its relevance at the present time. Moreover, at the turn of the millennium the interest of researchers to the problem of bicameralism received a new impetus due to the latest attempts of constitutional reform of the upper chambers in a number of leading countries of Western democracy. Quite often one can even find the statement that bicameralism is a "key characteristic of liberal constitutionalism" (e.g., One Text Initiative, 2011, p. 11). Surely, since 2014 the new stage of economic and political dialogue in the framework of EU Eastern Partnership has brought to Ukrainian political spectrum severe risks of frustration and skepticism about European integration in case of failure to adopt relevant shapes of societal development (Tsybulenko \& Parkhomenko, 2016; Kerikmäe \& Chochia, 2016).

The authors of this article continue the scientific discourse in the sphere of bicameralism, contributing to the list of arguments that exist in modern legal literature in favor of Ukraine's transition to bicameralism. In the first section of this paper the authors have made an attempt to argue the thesis about the way how bicameralism may contribute to further diversification of state power, while in the second section they substantiate the positive significance of the upper chamber to strengthen the stability of the government in terms of a consensual, pluralistic democracy and semi-presidential government.

\section{The problem of bicameralism in modern scientific discourse}

The literature published in recent decades concerning the issues of bicameralism and the status of the upper chambers of parliaments is very extensive (see Tsebelis \& Money, 1997; Mughan \& Patterson, 1999; Joyal, 2003; Smith, 2003; Russell, 2000; Luther, Passaglia \& Tarchi, 2006). A special issue of the Journal of Legislative Studies deserves particular attention in this regard. This issue covered key political and legal aspects of modern bicameralism. All this confirms the validity of the statement that "the bicameralism persists in the modern world and causes unflagging interest both among theorists and practitioners, 
engendering particularly acute disputes during the preparation of the drafts of new constitutions or amendments to existing basic laws" (Avtonomov, 2013).

\subsection{Bicameralism as the theme of political discussions in Ukraine in terms of European integration}

In this context, Ukraine is not an exception, as there is a discussion in Ukraine on the need for a transition to bicameralism during the whole period of independence, at all stages of the new constitutional process. It is sufficient to recall that the bicameral structure of the parliament was envisaged by the first drafts of the new Constitution of Ukraine. In particular, in accordance with the draft of the Constitution of Ukraine, as worded on July 1, 1992, the parliament, which was suggested to be called the National Assembly of Ukraine, was to consist of two chambers: the Council of MPs and the Council of Ambassadors. The next draft of the new Constitution of Ukraine, as worded on May 27, 1993, also provided for the creation of a bicameral parliament; this time it was offered to be called the All-People's Council of Ukraine, and the chambers - the State Rada and Rada of Territories. Bicameralism was also envisaged in the draft of the Constitution of Ukraine dated February 24, 1996, where the return to the name "National Assembly of Ukraine" was announced, but with slightly different names of the chambers - this time they were offered to be called the Chamber of MPs and the Senate (Holovaty, 1997).

The adoption of the current Constitution, dated June 28, 1996, did not even stop the discussion on the optimal structure of the Ukrainian parliament (Constitution of Ukraine, 1996). In the future, the idea of a bicameral parliament, combining the interests of the people's representation with the representation of the interests of the regions, was embodied in the draft of the Law of Ukraine 'On Amendments to the Constitution of Ukraine', which was submitted for public discussion by the Decree of the President of Ukraine dated March 6, 2003. This draft provided for the creation of a bicameral parliament, which was to consist of the National Assembly and the Chamber of Regions. A similar approach was later provided for by the draft of the "people's" Constitution of Viktor Yushchenko in 2009, but with different names for the chambers, as suggested by the draft dated February 24, 1996, they were offered to be called the Chamber of MPs and the Senate.

However, we can trace an interesting detail: despite the known "public inquiry" for parliamentary bicameralism in Ukraine, the final decision is always in favor of monocameralism. This situation was not affected even by the results of the All-Ukrainian referendum of 2000, where the overwhelming majority of 
participants expressed their support for the transition to a bicameral structure of the Verkhovna Rada of Ukraine. Let us recall that 24,244,220 citizens of Ukraine, which constituted $81.68 \%$ of the total number of participants in the referendum, responded positively to the question: "Do you support the need to form a bicameral parliament in Ukraine, where one of the chambers would represent the interests of the regions of Ukraine and facilitate their implementation, and the introduction of appropriate amendments in the Constitution of Ukraine and electoral legislation?"

At the same time, the draft of the Concept of Amendments to the Constitution of Ukraine, which was taken as a basis by the Decision No. 14 of the Constitutional Assembly dated June 21, 2013, ignored the problem of bicameralism. There was no proper place for this problem in the work of the Constitutional Commission.

This attitude of the Ukrainian political elite to the problem of bicameralism clearly dissonances with European tendencies, where the problem of not only bicameralism at the domestic level but "bicameral Europe" is seriously discussed (see Senates and representation of local authorities, 2001). In this regard, it should be noted that the research of 2014 focused on the future role and institutional positioning of the European Committee of the Regions (CoR), five scenarios of the future provided forecasts of the evolution of the institutional and political role of the CoR, related powers and relations with other institutions and concerned parties of the European Union. The first and fifth scenarios in the context of the object of our research are of the greatest interest. The first-which is the scenario of a dynamic status quo-involves strengthening the consultative and political powers of the CoR without changing the EU Treaty, improving the quality and influence of its opinion on the legislative process. The fifth scenario describes the situation when the CoR would act as the third legislative chamber (along with the EU Council and the European Parliament) representing local and regional authorities. This scenario will require extensive revision of the EU Treaty in regard to creation of a strong and independent third chamber-the European Senate, which can influence the EU policies, guarantee institutional stability and represent the diversity of European collective components that the other two legislative chambers can not represent (Smith, 2003). The creation of the second chamber of the parliament, in the aspect of the European integration plans of Ukraine, would certainly be consonant with the tendencies of "bicameral Europe". 


\subsection{Bicameralism: pro and contra}

Addressing the scientific discourse on the problem of bicameralism, one should note the gradual transition of scientific research from a speculative, formal and legal, its examination in the context of the system and structural organization of the state apparatus, certain configuration of state power at its highest, political level, to the institutionalism based on generalization and analysis of significant empirical material, gained from the practice of parliamentary institutions of various world states (see Tsebelis \& Rash, 1995; Lijphart, 1984; Heller, 1997).

At the same time, the need to implement a bicameral structure of the parliament is still controversial.

Proponents of bicameralism believe that the bicameral structure of the parliament has a number of advantages over the unicameral structure, since, in particular, it implies a more complete consideration of the interests of various social, economic, cultural groups or geographical units through the expansion of representation of sub-national authorities; creation of prerequisites for representation of regional interests at the national level, etc. The positive quality of the bicameralism is often indicated by the presence of restraining mechanisms (when the upper chamber becomes a sort of deterrent to the lower one), which provides a more balanced legislative process, where the chambers act as independent expert institutions, and as a result, the impossibility of making unconsidered legislative decisions. It is also noted that bicameralism in terms of a pluralistic democracy ensures balancing of the multi-polar forces in the parliament, since the political evaluation of the activities of one chamber is supplemented by a political comparative assessment from the position of another chamber.

Sometimes, among the advantages of bicameralism, it is noted that it can lead to some optimization of the activity of the chambers by raising the professional level of the deputy corps and reducing the number of their deputies, which facilitates constructive discussion of issues and making balanced decisions, as well as to the increase in the publicity of the legislative process and other parliamentary procedures. It is believed that the bicameral system contributes to the improvement of legislative work due to the fact that the duties of the upper chamber include a thorough check of often hasty decisions of the lower chamber, playing the role of a "filter" in the legislative process. It is often emphasized that bicameralism, in the context of constitutional design, contributes to the balance in the state mechanism between the legislative power, the head of state and the executive power (e.g., Lijphart, 1999; Slovska, 2013; Loomis \& Manning, 2014). 
The main advantages of the bicameral system according to J. Mastlas and L. Grange (1987) in the systematized form are as follows: both chambers mutually restrain each other in the sphere of power; the bicameral parliament more effectively restrains the executive power; the bicameral parliament provides for a broader representation of electorate, especially in multinational countries; the presence of the second chamber ensures a more thorough study of draft laws; the second chamber acts as a guarantor of the Constitution, since the terms of passing the controversial bills are extended, which gives additional time for consideration of the bill and its public discussion (Mastlas \& Grange, 1987).

It is also important that bicameralism ensures the impossibility of introducing unexpected and drastic changes in the implementation of the state policy after subsequent elections, since elections of chambers are carried out in different terms and according to different electoral systems. This feature of the bicameral system has been pointed out by the classical authors of constitutionalism. "The separation of the legislative corps," Bentham noted, "greatly hinders the reforms with any composition of the chambers [...] The state ship, reinforced by two anchors, acquires such a resistance force that it could not ever achieve by any other means" (Bentham, 1816). The quality of bicameralism seems rather controversial for Ukraine, which at the present stage requires a lot of socioeconomic, political and legal reforms, but in the long-term perspective, when stabilization and consolidation of the obtained results is required, it certainly can play its positive role.

In turn, the idea of the bicameral parliament raises anxiety and concern on the part of many domestic government experts who believe that the appearance of the second chamber can be an additional incentive for the federalization of Ukraine, and can threaten the integrity and inviolability of its territory. There is also a fear that bicameralism can significantly complicate and, as a result, slow down the legislative process due to significant differences between the chambers; consequently, a rapid response to changes in the socio-political and socio-economic life of the country will become impossible. Some authors argue that the emergence of the second chamber can create an artificial confrontation between the chambers and political demarcation, lead to the emergence of political central lines "the chamber of the parliament-the government", "the chamber of the parliament - the head of the state" and, as a consequence, threatens to further aggravate contradictions between the supreme agencies of the state, which can be accompanied by a permanent struggle between them for the dominant position in determining the beginnings of domestic and foreign policy, or weaken the Verkhovna Rada of Ukraine and make it dependent on the executive authorities (Fisun, 2008; Zhuravsky, 2001; Slovska, 2013). 
It should be noted that among foreign researchers there are many critics of the bicameral parliament. Thus, in the above-mentioned work, Mastlas and Grange (1987) point out the following disadvantages of bicameralism: the second chamber often acts as a brake of democracy, especially when its members are not elected or are elected through indirect elections; the second chamber contributes to conservatism in politics, since it supports existing constitutional arrangements and sometimes reflects the interests of only the ruling elite; the bicameral parliament may restrict access to the policy definition process, since the final development of legislative acts is in the hands of the joint committees. However, supporters of bicameralism argue that the bicameral legislature is the guarantor of better legislation, greater representativeness and greater pluralism of opinions (Mastlas \& Grange, 1987).

“The strength of bicameralism," Lijphart (1999) reasonably points out, "depends on two criteria: the symmetry and incongruence of the two houses of the legislature". However, two chambers are considered to be symmetrical, if they are equally sovereign and both are elected directly by voters, through universal, equal and direct elections, and therefore both have full democratic legitimacy. At the same time, two chambers of the parliament are incompatible if they differ significantly in their composition. In turn, B. Loomis and H. Manning rightly point out that "by design, bicameral legislatures often produce tensions between lower chambers, with their direct, localized ties that often link members and constituents, and upper chambers by varying sizes of constituencies and electoral mechanisms" (Loomis \& Manning, 2014). In our opinion, bicameralism in Ukraine is justified only in the "strong" version; otherwise the second chamber will initially have a rudimentary nature, which will only discredit the very idea of bicameralism. Meanwhile, one must be prepared for the fact that relations between the chambers, especially in the first years after the implementation of bicameralism, will not be easy: according to the experience of many countries in the world, the effective functioning of the bicameral parliament and the establishment of a constructive dialogue between chambers requires time and the accumulation of positive law-enforcement practice.

Quite common is the thesis that the second chamber has the right to exist only in a federal state, where it represents the interests of the subjects of the federation (e.g., see Svyatotsky \& Chusenko, 1998; Dhami \& al-Nowaihi, 2007; Bordenyuk, 2011; Hickey, 2013). The famous French political scholar Marcel Prelo believed it expedient to have the second chamber of the parliament (Prelot, 1955). Naturally, any reference about federalization is met with apprehension, and sometimes even a strong protest in today's Ukraine, which is facing serious challenges to its territorial integrity. Similar emotions are caused by all related 
phenomena, including bicameralism. In this regard, it should be specially emphasized that bicameralism itself does not threaten unitarism: bicameral parliaments are inherent not only in the federal but also in the unitary states; only in Europe there is a dozen of them. Another thing is that the federal form of the state structure presupposes the existence of the second chamber as an agency for representing the interests of the subjects of the federation. In other words, the connection here is of an opposite nature: the federal form itself determines the bicameralism of the national parliament, but bicameralism itself does not require federalization at all.

In general, the upper chambers are often characterized as "embodying a particular measure of wisdom, balance and expertise" (Gélard, 2006). The high authority of the senators indeed has a direct positive impact on the quality of the debates and consultations in the work of the upper chamber, as a result of which the political weight of the chamber itself and the parliament on the whole is increased. It seems that the Ukrainian parliament has often lack of this.

Throughout the 20th century, the number of bicameral parliaments has steadily declined, convincingly confirming the position of skeptics of the bicameralism. Thus, the periodic analytical reports of the Inter-Parliamentary Union and the results of expert studies recorded a steady decline in the bicameralism, especially in unitary states. So, in 1961 the share of bicameral parliaments was 59\%, in 1976 it was $46 \%$, in 1986-34\% and in 1996-33\% (according to IPU, 1962; Herman \& Mendel, 1976; IPU, 1986; Coakley \& Laver, 1997). This tendency was universally recognized and was observed not only at the national, but also at the sub-national level (except for Australia and the USA) (Massicotte, 2001).

However, after the collapse of the "communist camp" and the overthrow of authoritarian regimes in other countries, many of the successor countries returned to the bicameralism, both in the Philippines (1987), Poland (1989), Romania (1990) and Ethiopia (1995). In the early 2000s, the situation changed even more radically and the number of the bicameral parliaments began to increase rapidly both in gross and in percentage terms. Between 1996 and 2012, there were at least 28 new second chambers, 19 of them in Africa and the Middle East, 4 in Asia and 5 in Europe and on the territory of the former USSR. During the same period, only 9 countries moved in the opposite direction - to the unicameralism (Coakley, 2012).

While in the 1970s the bicameral legislature had about 45 countries around the world, by now this indicator has risen to almost 80 countries (Forum of the World's Senates, 2000). In April 2014, 79 bicameral systems (41.15\%) and 113 
unicameral systems were registered in the database of the Inter-Parliamentary Union. Of course, not all states that gave preference to bicameralism can serve as a model of democracy, especially in case of Africa and the Middle East, but it is more important for Ukraine than for others, in the light of its pro-European aspirations.

The European Union itself is considered to be a unique platform for testing all the existing legislative models of liberal democracies. In countries that the IPU considers to be in the European region, the ratio is approximately the same: 17 countries with a bicameral system (35.42\%) and 31 with a single chamber (Drexhage, 2015). Among the 28 EU Member States, 13 of them, that is almost half, have chosen bicameralism. Yet, accession to the EU has raised a number of questions on the constitutional status of national parliaments. For example, in Estonia the delegation of legislative drafting and decision-making from parliament to government representing the state at supranational level was highly debated and resulted in the subsequent amendments to the statute (Kerikmäe, 2016).

Herewith it is important to note that among the reasons underlying this process, it is increasingly indicated that "without necessarily seeking to embrace federalism, many of the world's nations are pursuing decentralization policies which justify an independent representation at central level, and bicameralism is the only system appropriate for such contexts". As the Venice Commission report of 2006 states, the second chambers are "necessary, and will become increasingly so, in federal states and ones that are constitutionally regionalized or heavily decentralized, where second chambers represent geographical areas whereas first chambers represent peoples" (Gélard, 2006). Therefore, in the conditions of the constitutional reform being carried out in Ukraine regarding the decentralization of power, the issue of the transition to the bicameral parliament is not only appropriate, but even necessary.

M. Russell in her article 'What are second chambers for?' singled out four factors that justified the existence of the second chambers: (1) the representation of different interests, (2) the independence from the executive, (3) the acting as a veto-player and (4) the performance of different parliamentary duties (Russell, 2001). This argument is taken as the basis for the arguments of many other bicameralism supporters (Schmitt, 2014), but it can hardly be called complete and comprehensive. 


\section{Advantages of bicameralism: several additional arguments for Ukraine}

Being consistent supporters of bicameralism of the Ukrainian parliament, we consider it necessary to make several additional arguments. Recently, there are many scientific articles, the authors of which pay particular attention to the analysis of bicameralism from the point of view of public choice and rational actor of politics analysis, within the framework of concepts of deliberative and participatory democracy (see Riker, 1992; Brennan \& Hamlin, 1992; Bradbury \& Crain, 2002; Congleton, 2003; Goot, 1999; Aroney, 2008). The results of the studies of the above-mentioned authors provide grounds for making additional arguments in favor of bicameralism. All of them, to one degree or another, concern two important aspects: the diversification of power and the strengthening of the "survivability" of the government.

\subsection{Bicameralism as the way to diversify the power}

Let us start with the diversification of power (in English, a diversified system of governance). Most modern constitutionalists agree that unicameral parliament and the combination of the presidency with the executive power in a centrally controlled country are a real problem for democratic governance. Therefore, at the present time, the theme of decentralization in its various manifestations like deconcentration, delegation, devolution, privatization, is the red thread of reforms in the sphere of the organization of public power. However, the essence of all these processes lies in the dispersal of power, eliminating the possibility of concentrating excessive power in one hand, ensuring the competitiveness of power decisions. In this aspect, bicameralism can also be viewed as a manifestation of the diversification of the legislative power. Naturally, such a diversification can only take place when the upper chamber has real opportunities to influence the process of drafting and adopting legislative acts, to participate in determining the significant elements of their form and content.

Many modern political scholars and constitutionalists, who consider the bicameralism as a means of a democratic parliamentary system, distinguish between two essential aspects: a different institutional basis and different "political make-up" (Tsebelis \& Rash, 1995). All this involves institutionalized groups with specific interests in the work of the legislative agency that are very important for a society. In particular, Arend Lijphart, discussing the issue of majority and consensus democracy, sees the special meaning and significance 
of bicameralism for pluralistic societies (harshly divided according to religious, ideological, linguistic or racial characteristics, which forms subcommunities separated from each other), for which the model of consensus democracy matches (see Lijphart, 1984). Indeed, bicameralism refers to those constructive features of legislative institutions that make possible the processes of representative government, taking into account the diversity of voters' opinions to the maximum.

The idea of a bicameral structure of the parliament is based on the recognition of the fact that the society is heterogeneous in its composition with a large number of different interests. Modern democracies try to take this recognition into account by creating different forms of making political decisions. However, it is impossible to simultaneously consider the diverse interests of all groups and individuals. It is not easy to determine which of the many interests should be institutionalized, and in which form. There were attempts to make progress in the framework of bicameral parliamentarism in terms of the legislative agencies, to which the idea of bicameral parliaments primarily belongs.

In case there is a stable majority in the lower chamber, there is always a threat of trampling down the interests of those social groups and layers whose interests are represented by the parties that are in the opposition. Such parliamentary majoritarianism, with all its formal democracy, reduces the legitimacy of the legislative agency, deprives it of support from a significant part of the population that feels "irrelevancy" for the authorities, leads to the spread of protest sentiments, and in its extreme manifestations can lead to open civil confrontation. In these conditions, the appearance of the second, upper chamber provides the parliament "double legitimacy" and, in turn, strengthens its support among the bulk of the electorate.

On the other hand, the presence of the upper chamber broadens the electoral basis of the parliament, allows the parties that did not pass into the lower chamber, or which were in a minority, to take revenge during the elections to the upper chamber. In turn, the broader the electoral base of the current parliament is, the higher is its viability and stability, and the more significant is its role in the life of the state and society.

Besides, the broad electoral basis of the bicameral parliament makes it possible (with the appropriate electoral system) to more clearly grasp and reflect the opinion of the regional elites and, therefore, to counteract separatism by solving the accumulated problems within the legislation. This quality of bicameralism prevails for the modern Ukraine, which is socially and territorially divided. 
It should be noted that all the second chambers of parliaments of the Member States of the European Union, with the exception of the Irish Senate and the House of Lords of the United Kingdom and, to a lesser extent, the Italian Senate, are agencies of representation of sub-national territorial entities (provinces, regions, departments, municipalities, etc.). Regarding some of them, as in France and Spain, this role of territorial representation is specifically enshrined in the text of the Constitution. For example, the Senate of France is defined by the Constitution of 1958 as a representation of the territorial communities of the Republic (la représentation des collectivités territoriales de la République)(Art. 24). The senators are elected by the electoral collegiates in each department, notably the design of the electoral system leads to a clearly excessive representation of rural areas, which is the reason why the French Senate is sometimes called the Chambre d'Agriculture, or the Agricultural Chamber. Taking into account the fact that the rural population of Ukraine is about $30 \%$, the French experience of bicameralism seems to be very exhortative.

In this regard, it is noteworthy that only senates of Italy, Poland, the Czech Republic and Spain among the upper chambers of the parliaments of the Member States of the European Union, are elected (partially) by direct elections; all the others are formed indirectly. This is a bright indication that the ability of the upper chambers of parliaments to represent the interests of the regions is not directly dependent on the procedure of their formation. Moreover, in case of indirect formation, the upper chamber is less susceptible to the influence from the ruling parties and, as a consequence, to the impact from the government.

It is important to note that representation of interests of sub-national entities in conditions of bicameralism is achieved, as a rule, with a fairly compact nature of the upper chamber. In Europe, the United Kingdom is the only country with the Senate that is larger-even much larger - than the Lower House. The Upper House had, and still does have, an unusually large number of members, although their number was cut from about 1200 in 1999 to about 780. Outside Europe, only Kazakhstan and Burkina Faso had until recently a senate that was larger than their lower house, but Kazakhstan's has since been cut to 47 members (compared with 115 in the lower house) and Burkina Faso abolished its senate, but then decided to reinstate it in 2013, this time consisting of 89 members (the lower house has 127) (Drexhage, 2015). This is a serious argument in the dispute with those who may see a threat of "swelling" of the deputy corps in the second chamber.

“The composition and powers of senates,' M. Wasowicz (1992) notes, “display a very great variety. They more often appear to be the result of historic 
compromises". However, as a result of any such compromise, the appearance of the second chamber of the parliament naturally leads to a redistribution of power at the highest level of the state organization, to a significant change in the composition of public authority in the country. Even S. Ganghof suggests to consider bicameralism in general as a form of legislative organization, but as a special form of government - a kind of hybrid between parliamentarism and presidency (see Ganghof, 2014).

The formation of the second chamber as an agency of regional (territorial) representation makes it possible to remove a considerable amount of the state affairs from the bureaucracy and transfer it to the local elites. Thus, there will be a "horizontal" decentralization of the state (legislative) power. At the same time, the lower chamber will have to act as a deterrent, so that centrifugal tendencies can not break the unity and integrity of the state.

\subsection{Bicameralism as the way to strengthen government stability}

Regarding the importance of the upper chamber for the stability of the government, according to Jeremy Waldron (2012), another approach to the executive power is that it is the most important difference that can be established between the two chambers under the Westminster system. It is unlikely that this feature can be considered as the most significant for characterizing the differences between the chambers of the parliament under any form of government, but its role in any case should be admitted as deserving special attention.

Waldron (2012) notes the weakness of the lower chamber in relations with the government, explaining this by the requirements of party discipline and the desire of MPs to get a ministerial portfolio sooner or later. In our opinion, this approach is somewhat simplistic, but on the whole, the government's significant influence on the work of the lower chamber can not be denied. Under these circumstances, the upper chamber can indeed serve as an important element in the separation of powers in terms of ensuring the sovereignty and independence of the parliament as an agency of legislative power in relations with the government. This is particularly evident in case of a discrepancy between the party majority in the upper and lower chambers.

In the case of Ukraine and other countries of transit democracy, the reverse side of this problem is also important. The fact is that in the countries which are mixed, semi-presidential republics by the form of the government, where the government is traditionally under the significant influence of the head of the state, the parliament is poorly structured, and the party system is extremely 
undeveloped, it is important to ensure independence of the government from the parliament rather than vice versa. Also, the presence of the upper chamber can help in resolving this issue.

We can not allow the fate of the government depend on the will of the parliamentary majority which is not structured in a party sense (and hence, in fact, not bearing political responsibility to voters) and is extremely inconstant.

The experience of Ukraine is quite eloquent in this respect. During its 26 years of independence, 16 governments have been replaced in Ukraine (not including temporary acting duties), that is, the average "life expectancy" of a Cabinet of Ministers of Ukraine is about one and a half years. Let us recall that during the same period of time, Ukraine has had only five presidents and seven convocations of the Verkhovna Rada, and notably some MPs managed to change their party and factional membership several times during one convocation. Simple mathematical actions allow us to conclude that during a presidential term, the composition of the government changed on average three times, and more than twice during one convocation of the Verkhovna Rada. Government leapfrog is a thing that always adversely affects both the state of the economy and the development of society and the state on the whole. In this regard, the attempts of government experts and political scholars to find ways to consolidate the positions of the government while preserving its responsibility under the parliament, as well as to increase its stability facing the challenges of the negative political situation in the country, are quite justified. And in this context, the presence of the second (upper) chamber is at the right time.

Even A. Esmein noted that the bicameral structure of parliaments is an important means of ensuring the balance of power branches, allowing the government to rely on one of the chambers in case of a conflict with another one (Esmein, 1896). Unfortunately, until recently there were practically no works focused on studying the influence of bicameralism on the coalition policy and the fate of the coalition government. To a large extent this is due to the fact that the government's "survival" almost never depends on the official decision of the upper chamber. However, studies conducted in the late 20th and early 21 st century convincingly demonstrated that bicameralism certainly affected the content and direction of the state policy (e.g., Hammond \& Miller, 1987; Tsebelis \& Money, 1997; Heller, 2001). After all, if the upper chamber has sufficient substantial powers in the legislative sphere, the government, striving to incorporate its policy into law, is forced to seek support in both chambers, regardless of the political forces in each of them. 
Recent studies, primarily the work of A. Lijphart (1984; 1999), P. Warwick (1992; 1994), and especially J. Druckman and M. Thies (2002), convincingly prove that the effectiveness, and eventually the duration of the "life cycle" of the government in conditions of bicameralism, depends not only on the lower, but to a great extent on the upper chamber. In particular, based on the data on more than 200 governments in 10 countries of the world, Druckmann and Thies (2002), as it were, "with figures in their hands", demonstrate that the risk of early termination of the government with the support of the majority in the upper chamber of the parliament, is reduced by $56.4 \%$, compared to when the government does not have such a support (see Druckman \& Thies, 2002, p. 624). It follows that the government responsible to the parliament (lower chamber), wishing to consolidate its political positions and thereby prolong its stay in power, can not ignore the wider institutional context of bicameralism. For Ukraine, this conclusion means that the transition to the bicameral parliament can serve as an additional mechanism in the system of separation of powers, and as an important factor in ensuring the independence of the legislative power and the stability of the government.

Talking of bicameralism in the aspect of the relationship between the parliament and the government, it should be noted that the government in the semipresidential republics, to which Ukraine belongs, is traditionally under the strong influence of the head of the state (this even gives grounds to some authors to talk about the "bicephalism" of the executive power). As a result, this leads to the fact that the president and the government, in fact violating the constitutional balance between the highest state authorities, often act as a "united front" in relationship with the parliament. It is extremely difficult for a single-chamber parliament to withstand such a double pressure, whereas the existence of the second chamber in this case makes it possible to balance forces at the top, political level of the state organization and thus, to guarantee the integrity of the state power and the unity of state policy, as well as to demonstrate the real power of people's representation.

It should be borne in mind that the upper chamber can not be dissolved by the head of the state, which increases the stability of the entire parliament and its independence in relations with the head of the state. Moreover, taking into account the potential impeachment to the president, in the procedure of which the two chambers of the parliament are involved, the head of the state is forced to reckon with the opinion of not only the lower chamber, which in the urgent case can be dissolved, but also the upper chamber, the fate of which he has practically no authorities to affect. 


\section{Conclusions}

Summarizing our arguments about the benefits of bicameralism, we can formulate the following conclusions:

Doubts about the benefits of bicameralism, expressed in modern literature, are primarily of a probabilistic nature and are built on its subjective perception. With a more careful and objective examination, it is found out that bicameralism in its political and legal nature is neither an attribute of federalism nor a catalyst for separatist tendencies. It is rather on the contrary, with a rational, balanced approach to resolving issues about the procedure of formation, size and competence of the upper chamber, bicameralism serves to strengthen statehood and the balance of the state apparatus at the highest political level, eliminates the basis for separatism and, on the whole strengthens the role of the parliament in the life of society and the state.

The implementation of the second chamber of the parliament into the constitutional design of Ukraine will fully correspond to the mainstream of the modern parliamentary reforms that have covered almost all regions of the world. It should be especially noted that this attitude of the Ukrainian political elite to the problem of bicameralism will attest to adherence to the newest tendencies of "bicameral Europe", which is extremely important in the context of Ukraine's European integration aspirations.

Bicameralism is able to increase the responsibility and quality of law-making and, possibly, even lead to overcoming political corruption in the parliament. One of the most important positive qualities of the upper chambers is their significant role in ensuring the diversification of the state power and the stability of the government. At the same time, these advantages of bicameralism largely depend on the degree of perfection of the constitutional design and institutional representation.

For Ukraine, as well as for other states at the stage of democratic transition, bicameralism should be used as a tool to ensure the balance of power at the highest political level of the state organization, as an arena for coordinating state and local interests, and the institutional guarantee of society against the threat of authoritarian revenge.

The issue of the transition to the bicameral structure of the Verkhovna Rada of Ukraine, because of its importance, should be returned to the orbit of scientific and political discussions held within the framework of the constitutional reform. 
This could be done through the creation of the fourth working group within the framework of the Constitutional Commission, focused on the implementation of parliamentary reform. As a result, a broad scientific discussion on the bicameralism problems should reach the level of concrete propositions for amending the text of the current Basic Law, which could become the object of discussion in the Constitutional Commission, and in the future - part of the bill on amending the Constitution of Ukraine in the aspect of parliamentary reform.

Professor Vasyl Tatsiy, PhD in Law, is Rector of Yaroslav Mudryi National Law University, Member of the National Academy of Sciences of Ukraine, Member of the National Academy of Law Sciences of Ukraine, Honorary President of the National Academy of Law Sciences of Ukraine. As a Member of the Constitutional Commission, he participated in the drafting of the Constitution of Ukraine (1996), was chairman of the working group of the Cabinet of Ministers of Ukraine for the development of the Criminal Code of Ukraine (2001), a member of the working group on drafting the Criminal Procedural Code of Ukraine (2012), and a member of the Coordinating Council for Judicial and Legal Reform. He participated in drafting the Statute of the International Criminal Court and in preparing many other bills. $\mathrm{He}$ is the author of more than 400 scientific works, including more than 40 monographs, textbooks and manuals. His working areas are the fundamental problems of criminal law (the basis of criminal liability, corpus delicti, the object of criminal and legal protection, etc.), the problems of theory of state and law (issues of the legal science methodology, comparative and legal studies and legal enforcement), constitutional law (modern constitutionalism, parliamentary law, etc.).

Professor Svitlana Serohina, PhD in Law, is Director of the Scientific Research Institute of State-Building and Local Government of the National Academy of Law Sciences of Ukraine, Head of the Department of State-Building of Yaroslav Mudryi National Law University, and Associate Member of the National Academy of Law Sciences of Ukraine. She is a Member of the Constitutional Commission established by the President of Ukraine in 2015, a member of Scientific Advisory Council of the Supreme Administrative Court of Ukraine, and a member of the Working Group on Improving the Territorial Organization of Power and Local Self-Government of the Ministry of Regional Development, Construction, Housing and Municipal Services of Ukraine; she is Head of the Commission on Administrative and Territorial System and Local Self-Government. She is involved in the examination of regulatory acts and works as a member of working groups on the development and improvement of the legal basis of local self-government. She has authored more than 150 scientific works. Her working areas are the constitutional and legal aspects of the form of government, parliamentary law, decentralization of public authority, territorial organisation of public authority and local self-government. 


\section{References}

Aroney, N. (2008), 'Four reasons for an upper house. Representative democracy, public deliberation, legislative outputs and executive accountability,' Adelaide Law Review, vol. 29, no. 2, pp. 205-246.

Avtonomov, A. S. (2013), 'Istoki i smysl dvukhpalatnosti parlamentov [The origins and meaning of bicameral parliaments],' Visnik Mariupol's'kogo derzhavnogo universitetu, vol. 5, pp. 35-42.

Bean, C. S. \& Wattenberg, M. P. (1998), 'Attitudes towards divided government and ticket-splitting in Australia and the United States,' Australian Journal of Political Science, vol. 33, no. 1, pp. 25-36. https://doi.org/10.1080/10361149850705

Bentham, J. (1816), Tactiques de assemblée legislatives, suivi d'un traité des sophismes politiques, 2nd vol., translated by Dumont, Geneva \& Paris: J. J. Paschaud.

Bordenyuk, V. I. (2011), 'Deiaki pytannia stvorennia dvopalatnoho parlamentu v Ukrayini u konteksti zarubizhnoho dosvidu [Some issues of creating a bicameral parliament in Ukraine in the context of foreign experience],' Derzhava i Pravo, vol. 51, pp. 201-208.

Bradbury, J. Ch. \& Crain, W. M. (2001), 'Legislative organization and government spending: cross-country evidence,' Journal of Public Economics, vol. 82, no. 3, pp. 309-325. https://doi.org/10.1016/S0047-2727(00)00150-X

Bradbury, J. Ch. \& Crain, W. M. (2002), 'Bicameral legislatures and fiscal policy,' Southern Economic Journal, vol. 68, no. 3, pp. 646-659. https://doi.org/10.2307/1061723

Brennan, G. \& Hamlin, A. (1992), 'Bicameralism and majoritarian equilibrium,' Public Choice, vol. 74, no. 2, pp. 169-179. https://doi.org/10.1007/BF00140765

Coakley, J. (2014), 'The strange revival of bicameralism', Journal of Legislative Studies, vol. 20, no. 4, pp. 542-572. https://doi.org/10.1080/13572334.2014.92 6168

Coakley, J. \& Laver, M. (1996), 'Options for the Future of Seanad Éireann,' in The AllParty Oireachtas Committee on the Constitution, Second Progress Report, pp. 32 107. Retrieved from https://www.constitution.ie/Documents/Oireachtas\%202ndReport-Seanad\%201997.pdf [accessed 9 Dec 2017] https://doi.org/10.1080/1357 2334.2014.926168

Congleton, R. D. (2003), 'On the merits of bicameral legislatures: policy predictability within partisan polities,' Jahrbuch für Neue Politische Ökonomie, vol. 22, pp. 29-49. Constitution of Ukraine (1996), Konstytutsiya Ukrayiny, Vidomosti Verkhovnoyi Rady Ukrayiny, 1996, 30, 141.

Constitutional Assembly of Ukraine (2013), Pro proekt Kontseptsiyi vnesennia zmin do Konstytutsiyi Ukrayiny [On the concept of amending the Constitution of Ukraine]. 
Retrieved from http://jurliga.ligazakon.ua/news/2013/6/20/ 93050.htm [accessed 9 Dec 2017]

Dhami, S. \& al-Nowaihi, A. (2007), 'Optimal distribution of powers in a federation: a simple, unified framework,'Bulletin of Economic Research, vol. 59, no. 3, pp. 197-229. https://doi.org/10.1111/j.0307-3378.2007.00257.x

Drexhage, B. (2015), Bicameral Legislatures: An International Comparison, The Hague: Ministry of the Interior and Kingdom Relations, Directorate of Constitutional Affairs and Legislation.

Druckman, J. N. \& Thies, M. F. (2002), 'The importance of concurrence: the impact of bicameralism on government formation and duration,' American Journal of Political Science, vol. 46, no. 4, pp. 760-771. https://doi.org/10.2307/3088432

Esmein, A. (1896), Éléments de droit constitutionnel, Paris: Librarie Larose.

Fisun O. A., ed. (2008), Dvopalatnyi parlament: svitovyi dosvid ta ukrayins'ki realiyi [Bicameral parliament: world experience and Ukrainian realities], Kharkiv: Zoloti Storinky.

Forum of the World's Senates (2000), Bicameralism around the World: Position and Prospects. Retrieved from http://www.senat.fr/senatsdumonde/forumdessenats/ senats_secondeschambresmonde/english/english-synthese.html\#fn1 [accessed 9 Dec 2017]

Ganghof, S. (2014), 'Bicameralism as a form of government (or: why Australia and Japan do not have a parliamentary system),' Parliamentary Affairs, vol. 67, no. 3, pp. 647-665. https://doi.org/10.1093/pa/gss081

Gélard, P. (2006), 'Parliamentary complexity or democratic necessity?' Council of Europe, European Commission for Democracy Through Law (Venice Commission) Report, 11.08.2006. Retrieved from http://www.venice.coe.int/webforms/ documents/default.aspx?pdffile=CDL(2006)059-e [accessed 9 Dec 2017]

Goot, M. (1999), 'Whose mandate? Policy promises, strong bicameralism and polled opinion,' Australian Journal of Political Science, vol. 34, no. 3, pp. 327-352. https://doi.org/10.1080/10361149950263

Hammond, T. H. \& Miller, G. J. (1987), 'The core of the Constitution,' American Political Science Review, vol. 81, no. 4, pp. 1155-1174. https://doi.org/10.2307/1962583

Heller, W. B. (1997), 'Bicameralism and budget deficits: the effect of parliamentary structure on government spending,' Legislative Studies Quarterly, vol. 22, no. 4, pp. 485-516. https://doi.org/10.2307/440340

Heller, W. B. (2001), 'Political denials: the policy effect of intercameral partisan differences in bicameral parliamentary systems,' Journal of Law, Economics, \& Organization, vol. 17, no. 1, pp. 34-61. https://doi.org/10.1093/jleo/17.1.34

Herman, V. \& Mendel, F. (1976), Parliaments of the World: A Reference Compendium, London: Macmillan. https://doi.org/10.1515/9783111691053 
Hickey, R. (2013), 'Bicameral bargaining and federation formation,' Public Choice, vol. 154, nos. 3-4, pp. 217-241. https://doi.org/10.1007/s11127-011-9815-x

Holovaty S. P., ed. (1997), Konstytutsiia nezalezhnoyi Ukrayiny [The Constitution of the independent Ukraine], vol. 1, Kyiv: Ukrainian Legal Foundation.

Inter-Parliamentary Union (1962), Parliaments: A Comparative Study on the Structure and Functioning of Representative Institutions in Forty-One Countries, London: Cassell.

Inter-Parliamentary Union (1986), Parliaments of the World: A Comparative Reference Compendium, vol. 2, New York: Facts on File Publications.

Joyal, S. (2003), Protecting Canadian Democracy: The Senate You Never Knew, Montreal: McGill-Queen's University Press.

Kerikmäe, T. (2016), 'Estonia as an EU Member State: Lack of pro-active constitutional dialogue,' in A. H. Morawa (ed.) Constitutional Evolution in Central and Eastern Europe: Expansion and Integration in the EU, Routledge, pp. 11-41.

Kerikmäe, T. \& Chochia, A., eds. (2016), Political and Legal Perspectives of the EU Eastern Partnership Policy, Cham, Heidelberg \& New York: Springer International Publishing. https://doi.org/10.1007/978-3-319-27383-9

Lijphart, A. (1984), Democracies: Patterns of Majoritarian and Consensus Government in Twenty-One Countries, New Haven: Yale University Press. https://doi.org/10.2307/j.ctt1ww3w2t

Lijphart, A. (1999), Patterns of Democracy: Government Forms and Performance in Thirty-Six Countries, New Haven: Yale University Press.

Luther, J.; Passaglia, P. \& Tarchi, R. (2006), A World of Second Chambers. Handbook for Constitutional Studies on Bicameralism, Milan: Giuffre.

Manning, H. \& Loomis, B. A. A. (2014), 'Bicameralism, Representation and Governance: An Australian-American Comparison,' Paper presented at Australian Political Studies Association Conference University of Sydney, Sydney, Australia, 28 September - 1 October 2014. https://doi.org/10.2139/ssrn.2500730

Massicotte, L. (2001), 'Legislative unicameralism: a global survey and a few case studies,' Journal of Legislative Studies, vol. 7, no. 1, pp. 151-170. https://doi. org/10.1080/714003865

Mastlas, J. \& Grange, L., eds. (1987), Les secondes chambres du parlement en Europe occidentale, Paris: Economica.

Mughan, A. \& Patterson, S. Ch. (1999), 'Senates: A Comparative Perspective,' in S. Ch. Patterson \& A. Mughan (eds.) Senates: Bicameralism in the Contemporary World, Columbus: The Ohio State University Press.

One Text Initiative Research \& Development (2011), An Introduction to Bicameral Legislature: Theory and Practice. Retrieved from http://www.onetext.org/wpcontent/uploads/2013/03/02_May-2011.pdf [accessed 9 Dec 2017] 
Prelot, M. (1955), Precis de droit constitutionnel, 3rd ed., Paris: Librarie Dalloz.

Riker, W. H. (1992), 'The justification of bicameralism,' International Political Science Review, vol. 13, no. 1, pp. 101-116. https://doi.org/10.1177/019251219201300107

Russell, M. (2000), Reforming the House of Lords: Lessons from Overseas, Oxford: Oxford University Press. https://doi.org/10.1093/acprof:oso/9780198298311.001.0001

Russell, M. (2001), 'What are second chambers for?' Parliamentary Affairs, vol. 54, pp. 442-458. https://doi.org/10.1093/parlij/54.3.442

Schmitt, P. (2014), 'Comparative Overview of Consultative Practices within the Second Chambers of EU National Legislatures,' European Committee of the Regions. Retrieved from http://cor.europa.eu/en/documentation/studies/Documents/ comparative-overview-of-consultative-practices-within-the-second-chambers-ofeu-national-legislatures.pdf [accessed 9 Dec 2017]

Senates and Representation of Local Authorities (2001), [Home page]. Retrieved from http://www.senateurope.org/eng/06062001.html [accessed 9 Dec 2017]

Slovska, I. Ye. (2013), Konstytutsiyno-pravovyi status parlamentu - Verkhovnoyi Rady Ukrayiny [Constitutional and legal status of parliament], Kyiv: Yurinkom Inter.

Smith, D. E. (2003), The Canadian Senate in Bicameral Perspective, Toronto: University of Toronto Press. https://doi.org/10.3138/9781442680609

Svyatotsky,A.\& Chushenko, B. (1998), 'Pytannia teoriyi i praktyky konstytutsionalizmu v Ukrayini' [Problems in the theory and practice of constitutionalism in Ukraine], Pravo Ukrayiny, vol. 2, pp. 17-20.

Tsebelis, G. \& Money, J. (1997), Bicameralism, New York: Cambridge University Press.

Tsebelis, G. \& Rash, B. E. (1995), 'Patterns of bicameralism,' in H. Döring (ed.) Parliaments in Western Europe: Majority Rule and Minority Rights, New York: St. Martin Press, pp. 365-390.

Tsybulenko, E. \& Pakhomenko, S. (2016), 'The Ukrainian crisis as a challenge for the Eastern Partnership,' in T. Kerikmäe \& A. Chochia (eds.) Political and Legal Perspectives of the EU Eastern Partnership Policy, Cham: Springer, pp. 167-180. https://doi.org/10.1007/978-3-319-27383-9_11

Uhr, J. (1999), 'Generating divided government: the Australian Senate,' in S. Ch. Patterson \& A. Mughan (eds.) Senates: Bicameralism in the Contemporary World, Columbus: The Ohio State University Press, pp. 93-119.

Waldron, J. (2012), 'Bicameralism': Public Law \& Legal Theory Research Paper Series, Working Paper 12-19, New York: New York University School of Law.

Warwick, P. (1992), 'Ideological diversity and governmental survival in Western European parliamentary democracies,' Comparative Political Studies, vol. 26, no. 3, pp. 332-361. https://doi.org/10.1177/0010414092025003003

Warwick, P. (1994), Government Survival in Parliamentary Democracies, New York: Cambridge University Press. 
Wasowicz, M. (1992), 'Les changements des attributions de la chambre haute des parlements en Europe au XIXe siècle et au début du XXe siècle,' in H. Blom, W. Blockmans \& H. de Schepper (eds.) Bicameralisme, Tweekamerstelsel vroeger en $n u$ - Handelingen van de Internationale Conferentie ter gelegenheid van het 175-jarig bestaan van de Eerste Kamer der Staten-Generaal in de Nederlanden, Den Haag, pp. 131-138.

Zhuravskiy, V. (2001), Ukrayins'kyi parlamentaryzm na suchasnomu etapi. Teoretykopravovyi aspect [Ukrainian parliamentarism on the modern stage. Theoretical and legal aspects], Kyiv: Instytut derzhavy i prava im. V. M. Korets'koho NAN Ukrayiny. 